\title{
Influence of High Speed Repetition of Pulsed Streamer Discharge Produced by Polarity-Reversed Traveling Wave on NO Oxidation
}

\author{
Eiji Matsuda Student Member (Ehime University) \\ Kazunori Kadowaki Member (Ehime University, kadowaki@eng.ehime-u.ac.jp) \\ Sakae Nishimoto Non-member (Ehime University, nisimoto@eng.ehime-u.ac.jp) \\ Isamu Kitani Member (Ehime University, kitani@eng.ehime-u.ac.jp)
}

Keywords : reciprocal traveling wave pulse, direct-grounding, high-speed repetition, NO removal, space charge effect

This paper describes experimental results of NO removal from a simulated exhausted gas using a barrier-type plasma reactor subjected to reciprocal traveling wave voltage pulses. A pulse-forming cable is charged and then grounded at one end without any resistance, so that a traveling wave reciprocates along the cable with a change in its polarity because the traveling wave is negatively reflected at the grounded-end. In an optical study, the reciprocal traveling wave voltage pulse was applied to a point-plane electrode system with a glass-barrier. Figure 1 shows a time-spectra characteristic of repetitive discharges produced by a $50 \mathrm{~m}$-long cable. Discharge light corresponding to the $2 \mathrm{nd}$ positive band of $\mathrm{N}_{2}$ molecules was detected for many times. The repetition number of the discharge decreased with increasing the cable

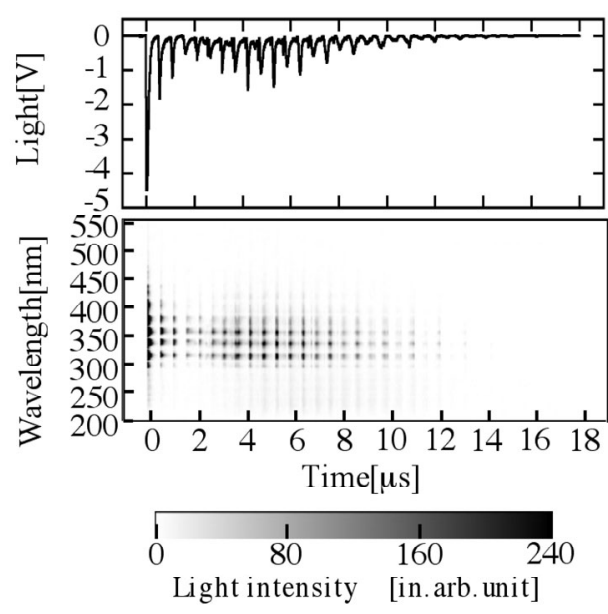

Fig. 1. Discharge light signal and the spectrum distribution

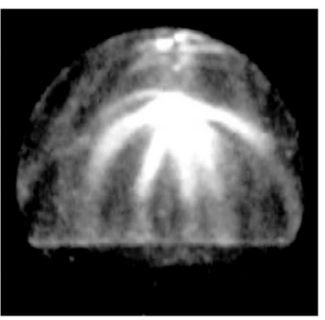

(a)

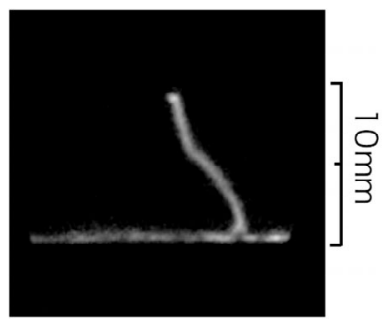

(b)
Fig. 2. Transient discharge light during voltage oscillation: (a)the initial stage and (b)latter stage length. This fact indicates that high speed oscillation caused by the reciprocal traveling wave in a short cable enhances the propagation capability of the subsequent discharges. In addition, we confirmed that the repetition number of the discharge increased with decreasing the oxygen concentration in the reactor.

Figure 2(a),(b) show temporal change in the repetitive discharge light during the voltage oscillation. The initial streamer discharge at the first polarity reversal stretched widely in the gap as shown in Fig. 2(a). However, only an intense discharge channel bridged over the gap at the latter stage in the voltage oscillation as shown in Fig. 2(b).

NO removal tests were carried out using the reciprocal pulse generator and a coaxial plasma reactor with a cylindrical glass-barrier. Figure 3 shows $E_{\text {all }}, E_{1}, E_{1+2}$ and $\eta$ in normalized scale as a function of cable length, where $E_{\text {all }}$ is total discharge energy during the voltage oscillation, $E_{1}$ is discharge energy at the first polarity reversal, $E_{1+2}$ is discahrge energy at the first and second polarity reversal and $\eta$ is NO removal ratio respectively. The dependence of $\eta$ on cable length was similar to that of $E_{1+2}$ on cable length. This indicates that the discharges at the first and the second polarity reversal contributed largely to the oxidation reaction from $\mathrm{NO}$ into $\mathrm{NO}_{2}$. On the other hand, the contribution of the subsequent discharges in the latter stage to $\mathrm{NO}$ oxidation was small as compared with that of the initial and the second discharges.

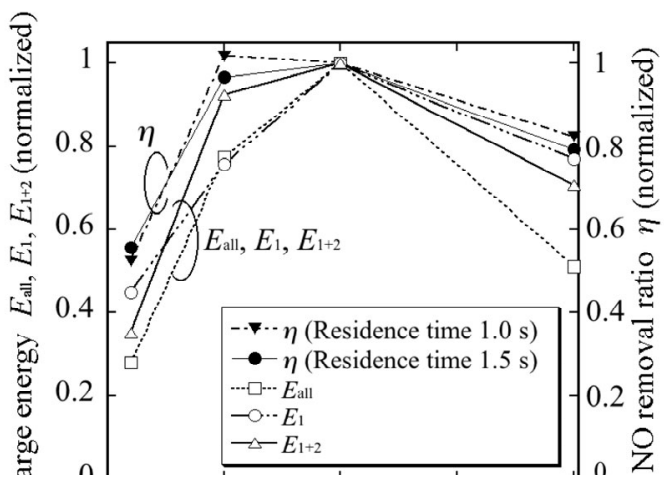

Fig. 3. Relations between $E_{\text {all }}, E_{1}, E_{1+2}$ and $\eta$ and cable length 


\title{
極性反転パルス放電によるNOの酸化処理 に対する高速繰り返しの影響
}

\author{
学生員 松田 栄司* 正 員 門脇 一則* \\ 非会員 西本 榮* 正員木谷 勇*
}

\author{
Influence of High Speed Repetition of Pulsed Streamer Discharge Produced by \\ Polarity-Reversed Traveling Wave on NO Oxidation \\ Eiji Matsuda*, Student Member, Kazunori Kadowaki*, Member, \\ Sakae Nishimoto*, Non-member, Isamu Kitani*, Member
}

\begin{abstract}
This paper describes experimental results of NO removal from a simulated exhausted gas using a barriertype plasma reactor subjected to reciprocal traveling wave voltage pulses. A pulse-forming cable was charged and then grounded at one end without any resistance, so that a traveling wave reciprocated along the cable with a change in its polarity because the traveling wave was negatively reflected at the grounded-end. Transient discharge light between point-plane electrodes with a glass barrier was observed using a gated image-intensifier. Photographs of the transient discharge light indicated that many streamer channels extended widely in the gap at the initial stage in the voltage oscillation, while only an intense discharge channel was observed at the latter stage. NO removal tests were carried out using the reciprocal pulse generator and a coaxial plasma reactor with a cylindrical glass-barrier. Results indicated that the discharges at the first and the second polarity reversals contributed largely to the oxidation reaction from $\mathrm{NO}$ into $\mathrm{NO}_{2}$, whereas the contribution of the subsequent discharges in the latter stage to NO removal was small.
\end{abstract}

キーワード：往復進行波パルス，直接接地，高速繰り返し，NO 除去，空間電荷効果

Keywords: reciprocal traveling wave pulse, direct-grounding, high-speed repetition, NO removal, space charge effect

\section{1. まえがき}

ディーゼルエンジン , 発電機あるいは火力発電所などか らの排出ガス中に含まれる室素酸化物 (NOx) を削減する ための応用研究が盛んである。NOx 処理方法としてょく知 られているものに，電子ビーム照射法 ${ }^{(1)}$, アンモ二ア選択 接触還元法 ${ }^{(2)}$ ，オゾナイザを利用したオゾン注入法 ${ }^{(3)}$ ，さ らには放電を利用した酸化処理方法 ${ }^{(4)}$ などが挙げられる。 放電を利用した処理方法をさらに分類すると，無声放電方 式，ペレット充填方式弚してパルス放電方式などが挙げら れる。パルス放電方式の場合，幅の短い高電圧パルスを繰 り返し印加することにより，電子温度のみが高く分子温度 は低いという非平衡プラズマ状態を比較的容易に形成でき るという利点があるため, これを用いた研究が数多くなさ

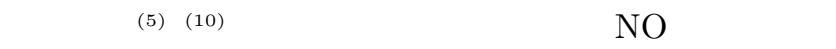

\footnotetext{
* 愛媛大学工学部電気電子工学科

₹ 790-8577 松山市文京町 3 番

Faculty of Engineering, Ehime University

Bunkyo-cho 3, Matsuyama 790-8577
}

し $\mathrm{NO}_{2}$ に変化させた後，生成された $\mathrm{NO}_{2}$ を還元処理する ことにより $\mathrm{N}_{2}$ にする方法が検討されており，還元処理方 法のひとつとして $\mathrm{Na}_{2} \mathrm{SO}_{3}$ 水溶液を用いた化学反応プロセ スか提案されている ${ }^{(11)}$ 。放電を用いた NOx 処理における エネルギー効率を検討する場合, プラズマ反応器内で消費 された放電エネルギーと排ガス処理量との関係について評 価するのが一般的である ${ }^{(12)}$ 。しかし, パルス電源を用いて 処理を行なう場合には，パルス形成線路に蓄積されたエネ ルギーを如何に効率良く放電エネルギーへと変換できるか という点にも注意を払うべきである。最近我々は，充電さ れた同軸ケーブルの一端を直接接地した時，もう一端に接 続されたバリア放電型反応器にパルス電圧が極性反転しな がら繰り返し印加されるという原理を利用した排ガス処理 方法について検討している ${ }^{(13) \sim(15)}$ 。この手法の特徽は, 1 回のスイッチングで放電を繰り返し引き起こすことができ る点と, ケーブル充電中に反応器内のバリア表面に蓄積さ れた電荷が，極性反転時における反応器内部の電界強度を 高める効果を有する点である。前報ではこれらの特徵が排 ガス処理に有効であることを明らかにしてきた ${ }^{(15)}$ 。すなわ 
ち，パルス形成線路の終端に整合抵抗の備わった単一パル ス発生器を用いた場合よりも高いエネルギー変換効率を得 ることができると共に，比較的波高値の低いパルスでも放 電を引き起こし得ることか確認された。しかし，極性反転 繰り返しパルスを用いた場合における単位放電エネルギー 当りの $\mathrm{NO}$ 処理量は, 単一パルスを用いた場合の产れより も低下するという問題点が今後の課題として指摘された。 単位放電エネルギー当りの処理量が低下する理由は, 数マ イクロ秒以下の短い周期で放電が繰り返されることにより, 放電の形態が高電界下で引き起こされるストリーマ放電か ら比較的低電界下でも持続可能な RF 放電に似たような放 電形態へと変化しているためと考えた ${ }^{(16)}$ 。しかしながら光 の詳細は不明であり，高効率な排ガス処理技術を確立する ためには，極性反転繰り返しパルス印加時の放電光の過渡 的変化についてさらに詳しく調べる必要がある。

このような状況のもと今回我々は, 誘電体バリアの挿入 された針対平板電極に極性反転繰り返しパルスを印加した 場合における, 放電スペクトルならびに発光像の過渡的変 化を調べた。本報は，ケーブル長やガスの組成が放電形態 に及ぼす影響について検討するとともに，同軸円筒型プラ ズマ反応器を用いて行われた NO 除去実験の結果について まとめたものである。

\section{2. 実験方法}

繰り返し放電の分光測定および発光像の過渡的変化を観 測するための光学系を含んだ実験装置の概要を図 1 に示す。 繰り返しパルス電圧発生装置の原理については, 前報 (14) (15) にて詳しく述べられているのでここでは产の概要を説明す るにとどめる。高抵抗を介して直流電圧 $-V$ の印加された 同軸ケーブル (フジクラ (株) : RG-8A/U) の一端は, 回 転スイッチを介して直接接地される。接地された終端のイ ンピーダンスはケーブルの特性インピーダンスよりも十分 小さいので, スイッチの投入と同時に伝搬を開始する進行 波は終端で極性反転しながら反射する。この反転した進行 波がもう一端に到達した時, 針対平板電極間の電圧は急激 に変化して放電が引き起こされる。誘電体バリアの存在に より進行波は正反射するので, 結果的に電極間電圧は $-V$ から $+V$ へと極性反転する。反応器内での放電によるエネ ルギー消費やケーブルの熱損失が，充電中に蓄積された静 電エネルギーよりも十分に小さければ，進行波は上に述べ た往復過程を繰り返すので, 極性反転パルスが何度も印加 される。本実験においては, 放電の繰り返し回数に対する 電圧パルス周期の影響を調べるために, 充電電圧が $-22 \mathrm{kV}$ 一定のもとで，長さ $10 \mathrm{~m}, 50 \mathrm{~m}, 100 \mathrm{~m}, 200 \mathrm{~m}$ の 4 種 類のケーブルを弚れ用いた場合に対して, 光学的観測 を行った。

図 2(a)〜 (c) は, 充電電圧 $-15 \mathrm{kV}$ における極性反転繰り 返しパルス発生装置の出力電圧波形である。これらの波形 は, 同軸ケーブルの出力端を開放した状態のもとで, 電圧 プローブ (Tektronix(株)：P6015A）を用いて測定された。

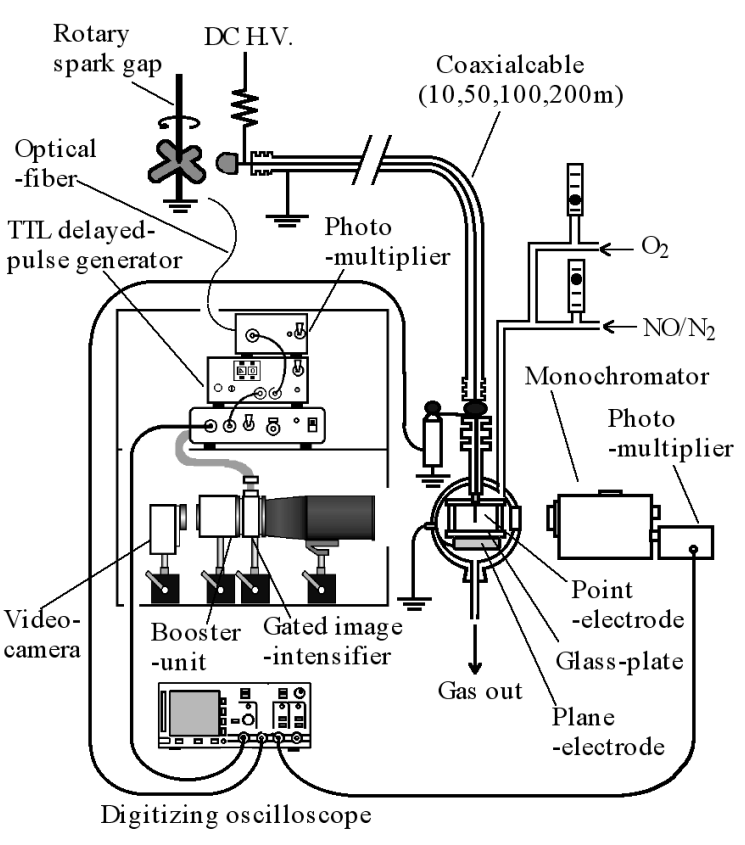

図 1 実験装置

Fig. 1. Experimental arrangements
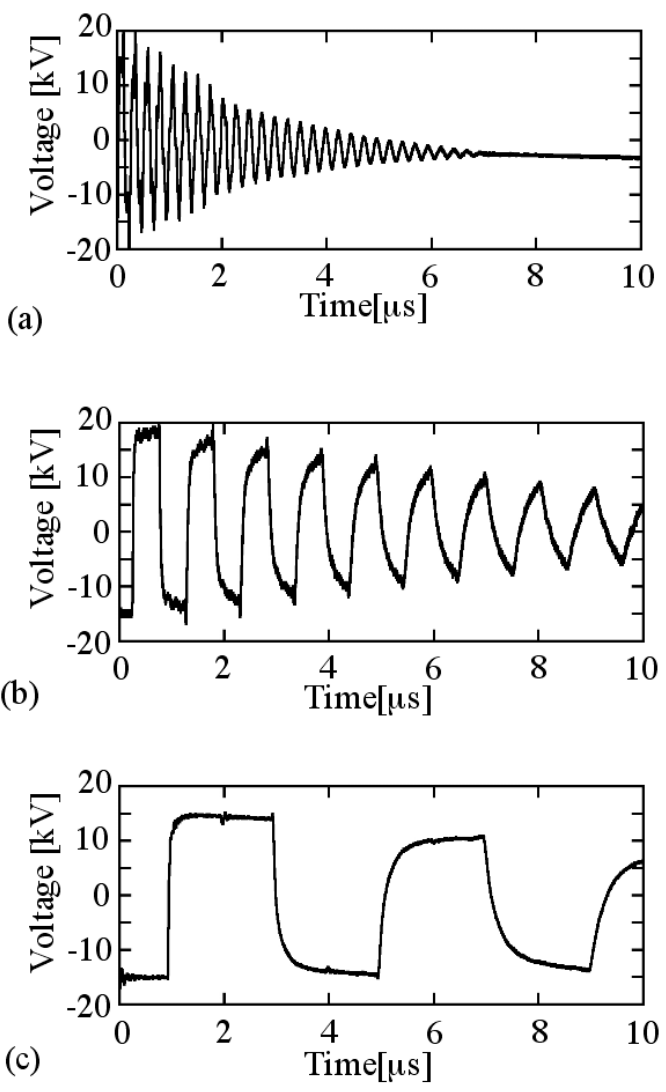

図 2 出力電圧 : (a)10 m, (b)50 m, (c)200 m

Fig. 2. Output voltage for various cable lengths: (a) $10 \mathrm{~m}$, (b) $50 \mathrm{~m}$, (c)200 m.

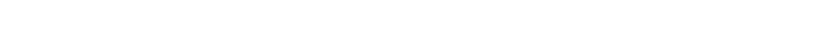
のに必要な時間と, パルス幅は一致しているのがわかる。 また, ケーブル長の変化に伴って, 立ち上がり時間に若干 
の変化か認められる。ケーブル長 $10 \mathrm{~m}, 50 \mathrm{~m}, 200 \mathrm{~m}$ に おける初回反転時の立ち上がり時間は光れ光れ $30 \mathrm{~ns}, 40$ $\mathrm{ns}, 100 \mathrm{~ns}$ である。ケーブル長 $200 \mathrm{~m}$ において立ち上が りが歪む理由は, 進行波の長距離伝搬の過程において高周 波成分が特に顕著に減衰するためと思われる。

先端曲率半径が約 $100 \mu \mathrm{m}$ のタングステン針電極 (直径 $0.5 \mathrm{~mm})$, 直径 $50 \mathrm{~mm}$ の真鍮円盤上にギャップ長が 10 $\mathrm{mm}$ となるようにして固定した。さらに平板電極表面を， 厚さ $2.0 \mathrm{~mm}$ のホウ珪酸ガラス板 (パイレックス) で覆い, これを誘電体バリアとして用いた。ガラスと平板電極との 微小な間隙に空気層ができないように，両者の界面には室 温硬化型の液状シリコーンを薄く塗った。石英莣付きの放 電管 (内径 $190 \mathrm{~mm}$, 長さ $300 \mathrm{~mm}$ ) の中央部に放電ギャッ プを配置した後, 窒素, 酸素および一酸化窒素が所定の比 率で混合された模擬排ガスを毎分 $1 \mathrm{~L}$ の割合で放電管へ 送り込みながら，大気圧下にて放電光を観測した。石英莣 と分光器 ((株) 島津製作所 : SPG-120S, スリット幅前後 とも $0.5 \mathrm{~mm}$ 固定, 分解能 $6.5 \mathrm{~nm})$ を通過した光を, 光 電子増倍管 (浜松ホトニクス (株) : H5783-03) で電気信 号に変換し , ディジタルオシロスコープ (Tektronix.Co. ; TDS7104) を用いて観測した。さらにスイッチを閉じた瞬 間に回転部で生ずる発光を電気信号に変換し，遅延回路を 介して高速ゲート付きイメージインテンシファイア (浜松 ホトニクス (株) : C2925-01) へ入力することにより，任意 の時刻における放電光の像を観測した。高速ゲートによる

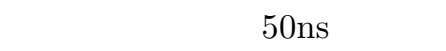

また，これら光学的観測とは別に, 前報 ${ }^{(15)}$ にて用いられ た同軸円筒型プラズマ反応器や亜硫酸ナトリウム水溶液槽 からなるシステムを用いて排ガス処理実験を行った。ケーブ ル長を変えながらエネルギー変換効率や NO 酸化処理効率 を測定し，排ガス処理における繰り返しパルスの周期が及 ぼす影響について調べ, 得られた結果と光学的観測におけ る結果との関連性を見た。本実験では, 内径 $18 \mathrm{~mm}$, 厚さ $1.0 \mathrm{~mm}$, 長さ $500 \mathrm{~mm}$ のガラス管の中心に直径 $0.5 \mathrm{~mm}$, 長さ $400 \mathrm{~mm}$ のタングステン線電極を挿入し，さらにガラ スの外周から直径 $21 \mathrm{~mm}$ の銅メッシュ製円筒電極を被覆 した構造のプラズマ反応器を用いた。反応器を通過後のガ ス中における $\mathrm{NO}$ 濃度を, $\mathrm{NOx}$ 検知管 (ガステック (株) : No.10) を用いて測定した。また，本実験では模擬排ガス を毎分 $1,2,4,6 \mathrm{~L}$ の割合で反応器に送り込み, 装置内 のガスの滞留時間を変化させた。前報で用いた反応器と比 ベて , 今回の光れは径方向の寸法が若干小さくなっている が , この変更を除けば , 処理システムの構成や計測方法に 関して前報からの変更は無い。

\section{3. 実験結果および検討}

〈3. 1〉 繰り 返し 放電光のスペクトル $\mathrm{N}_{2}$ が $85 \%, \mathrm{O}_{2}$ が $15 \%$, NO が 170 ppm の混合ガスを毎分 1 L の割合 で放電管へ送り込みながら極性反転繰り返しパルスを印加 した場合における発光スペクトルの強度分布の時間変化と，
強度分布の中から $315 \mathrm{~nm}$ の帯域だけを取り出して信号と して示したものを図 $3(\mathrm{a}) \sim(\mathrm{d})$ に示す。発光強度は, 濃淡 で表されている。図 3(a) のケーブル長 $10 \mathrm{~m}$ における時 間-波長特性を見ると，パルス印加開始から数マイクロ秒の 間に 30 回以上の放電が繰り返されているのがわかる。ま た，弚れらのスペクトルは, $300 \mathrm{~nm}$ から $400 \mathrm{~nm}$ の近紫外 領域に大きな強度を有することを示している。これらの強 いスペクトルは, 窒素分子の励起に起因する 2nd positive band とよく対応している。ここで注目すべきは，この帯域 の発光強度が繰り返し数の増加と共に減衰し続けるのでは なく，繰り返しの途中で強度が再び上昇するという点であ る。关の傾向は, 図 $3(\mathrm{~b})$ のケーブル長 $50 \mathrm{~m}$ においても明 らかに認められる。初回の発光強度が最も大きいのは当然 であるが, 初回印加から $4 \mu \mathrm{s}$ 後あたりで再び大きな発光パ ルスが検出されている。パルス電圧の波高值は繰り返し数 の増加と共に減衰しているにもかかわらず, 発光強度が繰 り返しの途中から上昇する事実は興味深い。この理由につ いては次項の発光像の観測結果と併せて考察する。

図 3(c) および図 3(d) を見ると，長いケーブルを用いた場 合には繰り返しの回数が少ないことがわかる。特に図 $3(\mathrm{~d})$ のケーブル長 $200 \mathrm{~m}$ においては, 2 回目の反転時以降に強 い発光が見られない。図 $3(\mathrm{a})$ (d) の光信号波形において， 波高值 $0.1 \mathrm{~V}$ 以上を有する発光パルスがいくつあるかを数 えて, その回数とケーブル長の関係を示したものが図 4 で ある。これによると，ケーブルが長くなるにつれて放電の 繰り返し数が減少していることがわかる。この事実は，パ ルス幅が長くなるほど充電された静電エネルギーを放電エ ネルギーへと変換する効率が低下することを示している。 このようなパルス幅に対する放電の繰り返し数の依存性を 理解するためには, 最初の放電によりギャップ間に形成さ れた空間電荷が, 兴の後の放電にどのような影響を与えて いるのかについて考える必要がある。混合ガス中の酸素濃 度を $15 \%$ から $7.5 \%$ もくは $0 \%$ にまで引き下げた状態 のもとで, $200 \mathrm{~m}$ のケーブルを用いた時の光信号波形を図 $5(\mathrm{a})$, (b) に示す。初回反転時の発光強度が最も大きいのは 当然として, ここで注目すべきは, 酸素濃度の低下に伴い, 2 回目以降の発光強度か増大している点である。このこと は, ストリーマの進展により電極間に形成された電子が , 次 の極性反転が起きるまでの期間に負性気体である酸素への 付着により負イオンを形成する確率が低いほど, 繰り返し 放電が起きやすいことを示している。すなわち酸素濃度が 比較的高い場合でも，パルス幅が十分に短ければ, 初回の 反転により進展した正ストリーマのチャネルに沿って，電 子か酸素に捕獲されることなく数多く残存し得るので, 次 の極性反転の時点で，多くの残存電子が電子なだれの初期 電子として作用するため, 結果として何度も繰り返し放電 が起きると説明できる。

発光強度の再上昇か湿著に現れたケーブル長 $50 \mathrm{~m}$ にお ける電圧, 電流, 発光波形を図 6 に示す。放電による発光は 電圧パルスの立ち上がりと立ち下がりに同期していること 

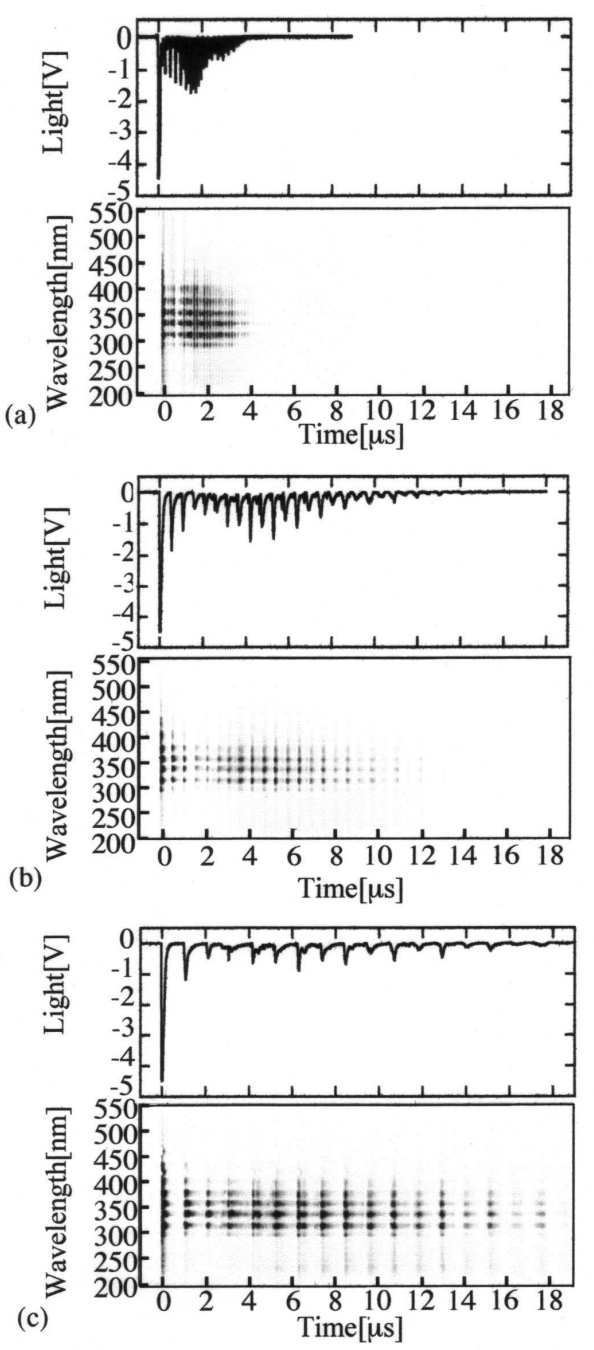

(c)

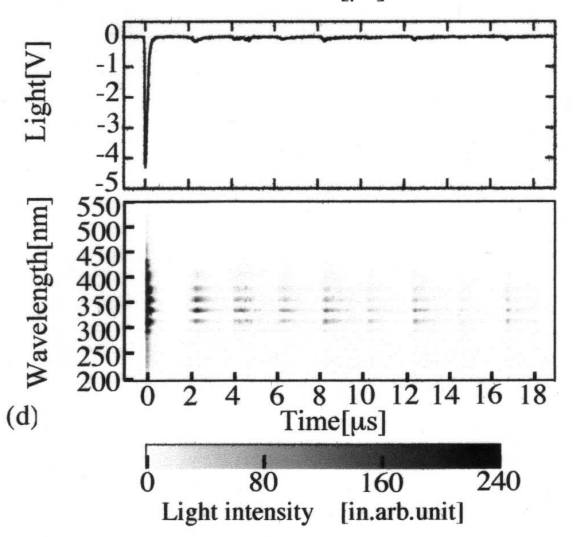

図 3 繰り返し放電光の時間一スペクトル特性 :

(a) $10 \mathrm{~m}$, (b) $50 \mathrm{~m}$, , c) $100 \mathrm{~m}$, (d)200 m

Fig. 3. Temporal change in spectrum of discharge light for various cable lengths: (a)10m, (b)50m (c) $100 \mathrm{~m}$, (d) $200 \mathrm{~m}$.

がわかる。極性反転時の放電開始電圧を統計的に調べたと ころ, $8.4 \mathrm{kV}$ の充電電圧において放電発生確率が $50 \%$ と なることがわかった。一方, 電流および発光強度が再上昇 している約 $3.2 \mu \mathrm{s}$ 後の波形をみると, 約 $5 \mathrm{kV}$ に達した時 点で放電が始まっているのがわかる。増田氏らはパルスを

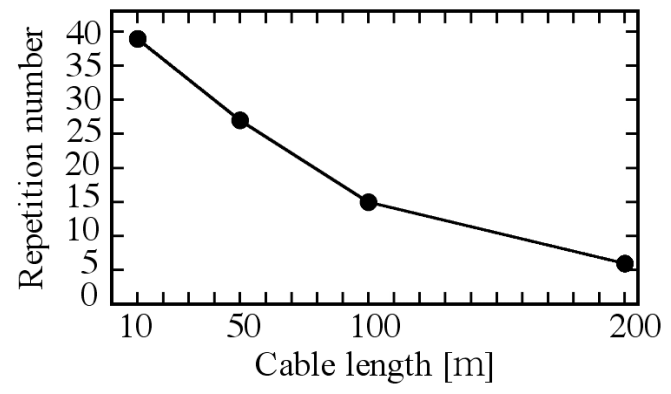

図 4 ケーブル長と発光回数との関係

Fig. 4. Relations between the repetitive number of discharge and cable length.
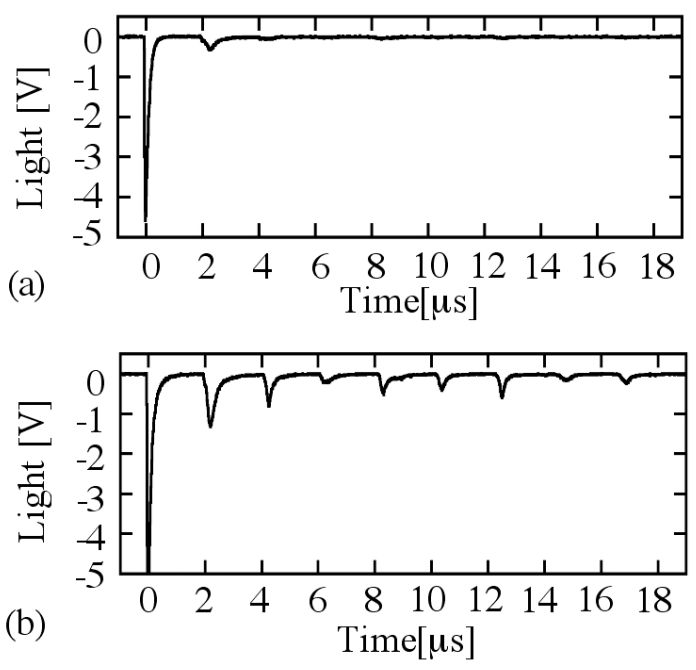

図 5 波長 $315 \mathrm{~nm}$ の光信号波形 (ケーブル長 $200 \mathrm{~m}$ )

(a) 酸素濃度 $7.5 \%$, (b) 酸素濃度 $0 \%$

Fig. 5. Light signals of wavelength $315 \mathrm{~nm}$ (cable length 200m) (a) $\mathrm{O}_{2} 7.5 \%$, (b) $\mathrm{O}_{2} 0 \%$.

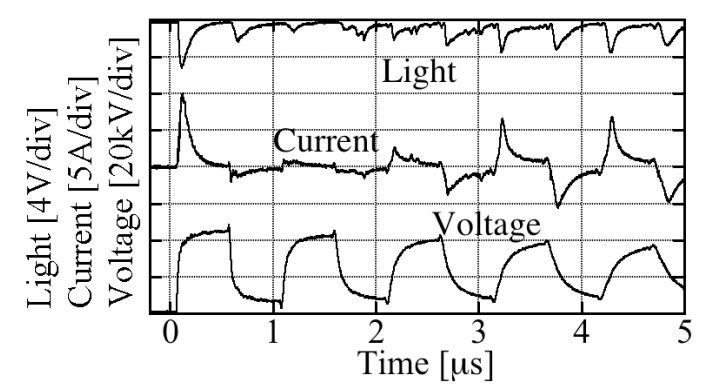

図 6 電圧, 電流, 発光波形 (ケーブル長 $50 \mathrm{~m}$ )

Fig. 6. Applied voltage, discharge current and discharge light signals (cable length $50 \mathrm{~m}$ ).

高速で繰り返し印加することにより放電開始電圧が低下す ることを報告している ${ }^{(7)}$ 。今回の実験においても，高速繰 り返しパルス印加の過程において , 同樣の現象が観測され たものと思われる。

〈3.2〉 繰り返し放電光の広がり 前節のスペクトル 観測結果において，繰り返しの途中で発光が再び強くなる という現象か顕著に認められた長さ $50 \mathrm{~m}$ のケーブルを用 

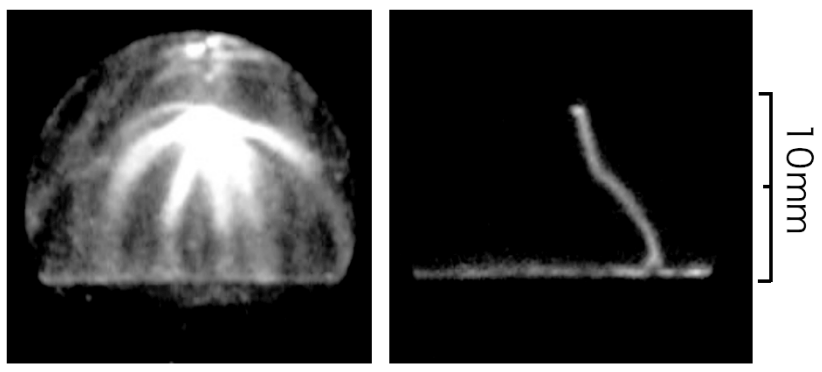

(a)

(b)

図 7 針先からバリア表面に進展する過渡的放電光 : (a) 繰り返し開始から $50 \mathrm{~ns}$ 後, (b) $4.25 \mu \mathrm{s}$ 後 (両方ともケーブル長は $50 \mathrm{~m}$ )

Fig. 7. Transient discharge light between pointplane electrode with a glass-barrier at (a) the initial stage (50ns) and at (b) the middle stage $(4.25 \mu \mathrm{s})$ of the voltage oscillation with 50 -m-long cable.

いた場合における過渡的放電光の写真を図 $7(\mathrm{a})$ および $(\mathrm{b})$ に示す。図 $7(\mathrm{a})$ は初回パルス印加時の放電の広がりを示 している。針先から平板電極に向かってストリーマ状の放 電が進展し，バリア表面に到達しているのがわかる。また， 数多くの放電チャネルが放射状に伸びており，比較的広い 空間が放電に曝されている。2 回目の極性反転時の放電光 についても観測したところ，ギャップ間に負ストリーマが 広がっていることを確認できた。図 7(b) は, 初回反転から $4.25 \mu \mathrm{s}$ 後における像である。強い発光を伴う放電チャネ ルが形成されているものの, 放電の広がりは認められない。 このような放電路の収縮現象と, 発光強度の再上昇は同じ 時期に起きていた。このことから，強度が再び上昇する理 由は, 放電の繰り返しにより空間電荷密度の非常に高い導 電路がギャップ間に形成されるために電流集中が起り，導 電路内での気体分子の励起が盛んになされるためであると 考えられる。放電路が一箇所に集中した状態で繰り返し放 電を引き起こしたとしても，排ガス処理率の向上は期待で きない。すなわち, 周期が短く波高值の十分大きな繰り返 しパルスを印加することにより放電を何十回と繰り返した としても，繰り返し後半の放電における排ガス処理への寄 与は小さいものと思われる。

一方, 長さ $200 \mathrm{~m}$ の場合, 初回反転時を除いて放電の広 がりは全く認められなかった。例えば 2 回目の反転時には， 針電極先端付近で微小な発光が生じているのみであった。 これらの結果は，極性反転が高速で繰り返されることによ り, 初回の放電で形成された電子群が次の放電の広がりを 促進し得るという考えを支持している。

〈3. 3〉NO 除去率と除去効率針対平板電極構成下で の光学的観測結果をもとに, 同軸円筒型プラズマ反応器お よび亜硫酸ナトリウム水溶液槽を用いて, 弚れどれのケー ブルにおける排ガス処理実験を行った。充電電圧を $-18 \mathrm{kV}$, スイッチング周波数 $12.5 \mathrm{~Hz}$ として， $\mathrm{N}_{2} 85 \%, \mathrm{O}_{2} 15 \%$, NO $170 \mathrm{ppm}$ の混合ガスを放電処理した場合の NO 除去 率とケーブル長との関係を, ガスの反応器内滞留時間をパ

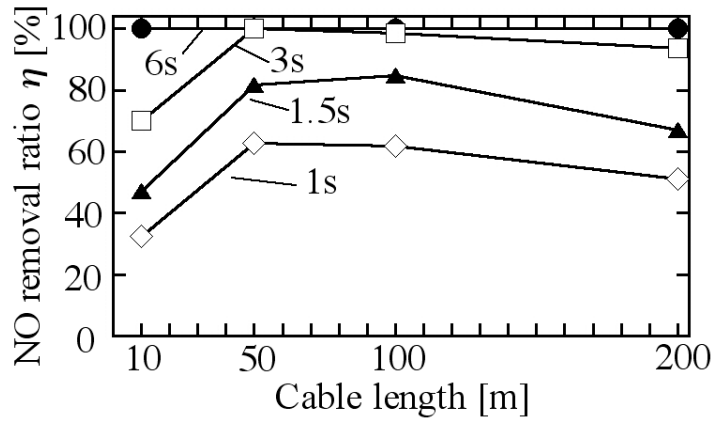

図 8 各滞留時間 (1 秒, 1.5 秒, 3 秒, 6 秒) に おけるケーブル長と NO 除去率との関係

Fig. 8. Relations between NO removal ratio and cable length for various residence times.

ラメータにして表したものが図 8 である。各条件にて 3 回 の測定を行い关の平均值を記している。充電電圧を少し低 く設定しているので, 放電光が繰り返しの途中で再び強く なる現象は，いずれのケーブル長においても起きなかった。 ここで図 8 の結果において , $50 \mathrm{~m}$ と $100 \mathrm{~m}$ のケーブルを 用いた場合に比較的高い除去率が得られた理由について考 察する。光学的手法による観測結果は, 繰り返し放電の後 半における NO 除去への寄与率が低いことを示唆した。す なわち, 初回反転時や 2 回目の反転時において引き起こさ れた放電が排ガス処理に大きく寄与しているとするならば， 初回や 2 回目反転時に消費された放電エネルギーのケーブ ル長への依存性は, NO 除去率の光れとよく対応するはず である。逆に, 全ての過程において消費された全放電エネル ギーのケーブル長依存性は, NO 除去率の光れとは異なる 傾向を示すと思われる。初回反転時に消費された放電エネ ルギーを $E_{1}$, 初回および 2 回目反転時に消費された放電工 ネルギーを $E_{1+2}$, 繰り返しの過程全体に渡って消費された 放電エネルギーを $E_{\text {all }}$, さらにNO 除去率を $\eta$ として , こ れらのケーブル長依存性を調べた。図 9 は $E_{1}, E_{1+2}, E_{\text {all }}$ および $\eta$ におけるケーブル長依存性を，ひとつのグラフに 重ねたものである。全ての項目において，ケーブル長 100 $\mathrm{m}$ における数値を 1 として規格化している。 $E_{\text {all }}$ のケーブ ル長依存性から，200 $\mathrm{m}$ における全放電エネルギーは, 100 $\mathrm{m}$ における弚れの半分しかないことがわかる。もしも全て の放電が排ガス処理に有効に作用するのであれば, $100 \mathrm{~m}$ における処理率は $200 \mathrm{~m}$ の 2 倍程度になるが, 実際には光 れほどの差は認められない。むしろ $\eta$ のケーブル長依存性 によく似ているのは $E_{1}$ および $E_{1+2}$ の光れであり，特に $E_{1+2}$ が良く対応している。すなわち図 9 は, 初回および 2 回目の放電が, NO 除去に有効に作用しているのに対し て, 弚れ以降の放電の NO 除去に対する寄与率は小さいこ とを示している。

図 10 は $E_{1} / E_{\text {all }}$ および $E_{1+2} / E_{\text {all }}$ とケーブル長との関 係を示したものである。前項において, 針先から伸びる放 電の繰り返し数はケーブル長の増大に伴い低下することが 示された。これに対して図 10 は, ケーブル長の短い $10 \mathrm{~m}$ 


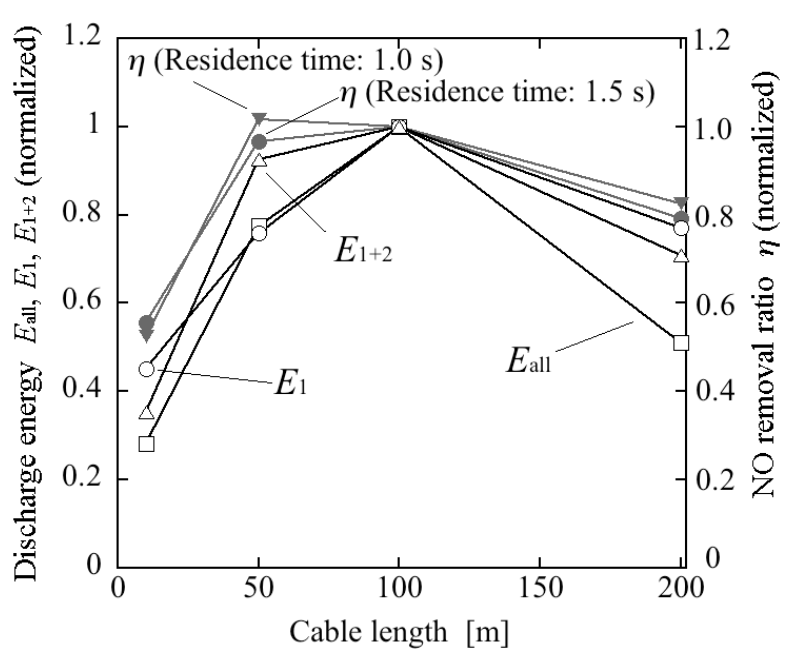

図 9 放電エネルギー $E_{1}, E_{1+2}, E_{\text {all }}$ および $\mathrm{NO}$ 除去率 $\eta$ とケーブル長との関係

Fig. 9. Relations between $E_{1}, E_{1+2}, E_{\text {all }}, \mathrm{NO}$ removal ratio $\eta$ and cable length.

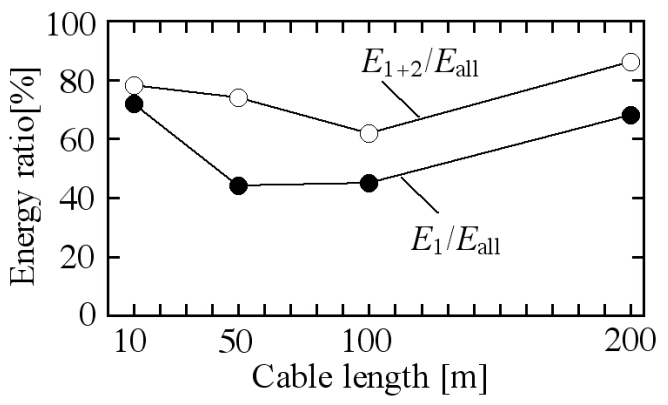

図 10 全放電エネルギーに対する初期放電 エネルギーの比率 $E_{1} / E_{\text {all }}, E_{1+2} / E_{\text {all }}$ と ケーブル長との関係

Fig. 10. Relations between energy ratios $\left(E_{1} / E_{\text {all }}\right.$, $\left.E_{1+2} / E_{\text {all }}\right)$ and cable length.

の場合に後半段階での放電によるエネルギー消費が少ない ことを示している。この理由は今のところ明らかでないが， $10 \mathrm{~m}$ の場合，広い空間で放電を繰り返すのに十分なエネ ルギーが蓄えられていないためではないかと考えている。 ギャップ長 $10 \mathrm{~mm}$ のバリア層付き針対平板電極ギャップに 比べて, 長さ $500 \mathrm{~mm}$ の反応器の方が, 1 回の放電により 消費するエネルギーは大きい。反応器内で放電を繰り返し ている時の電圧パルスの波高値の変化を調べたところ，50 $\mathrm{m}$ の場合には, 3 回目の反転時が $17 \mathrm{kV}$ で, 5 回目の反転 時でも $16 \mathrm{kV}$ を有していた。これに対して $10 \mathrm{~m}$ の場合に

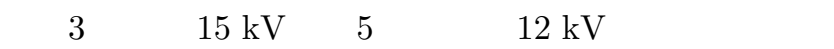
とを確認した。また，パルス形成線路に蓄えられた静電工 ネルギー $E_{\mathrm{s}}$ と $E_{\text {all }}$ との比，すなわちエネルギー変換効率 $E_{\text {all }} / E_{\mathrm{s}}$ は, $10 \mathrm{~m}$ の場合 $32 \%$ に達したのに対して, $50 \mathrm{~m}$ の場合は $17 \% ， 100 \mathrm{~m}$ においては $11 \%$ \%とどまった。こ れらの事実は, $10 \mathrm{~m}$ の場合 , 初期の放電によりパルス形 成線路に蓄えられていたエネルギーの多くが消費され，光

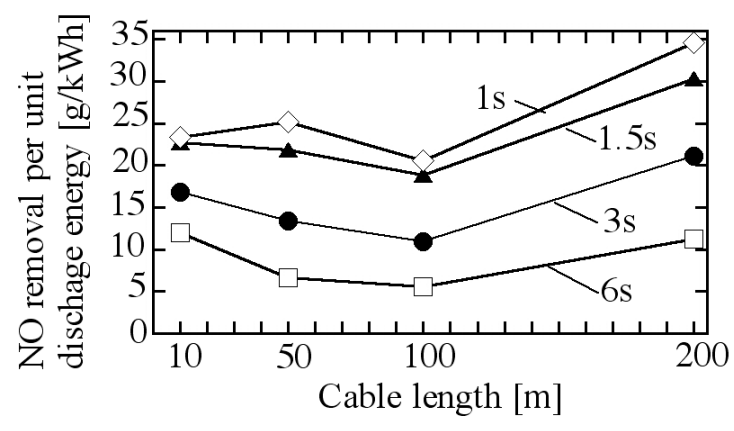

图 11 単位放電エネルギー当りの NO 除去量と ケーブル長との関係

Fig. 11. Relations between removal weight of NO per unit dischage energy and cable length.

の結果として繰り返し数が減少したという考え方を支持し ている。

単位放電エネルギー当りの $\mathrm{NO}$ 除去率を計算し，これを エネルギー効率とした。エネルギー効率とケーブル長の関 係を図 11 に示す。繰り返し後半段階での放電における NO 除去への寄与率が低いために , ケーブル長 $50 \mathrm{~m}$ と $100 \mathrm{~m}$ におけるエネルギー効率が低いことがわかる。1 回のスイッ チングにより放電を何度も繰り返すことができるという本 手法の利点を生かすためには, 繰り返し数か増えても処理 効率を低下させないための工夫が必要である。すなわち繰 り返し後半での放電の広がりを維持するため, 反応器の構 造に改良を加えた上で, 長さ数十メートルのケーブルを用 いるべきである。いずれにせよ今回の実験で得られた結果 は, ストリーマ放電の進展に伴い形成される空間電荷の振 る舞いが，次の反転時に進展する放電に大きな影響を及ぼ すことを示している。今後は，一本の電極から放電を放射 状に広げるのではなく，広範囲に配置された多電極群によ る微小放電を繰り返し引き起こすという方法について検討 を進める予定である。

\section{4. むすび}

誘電体バリアの挿入された針対平板電極に極性反転繰り 返しパルスを印加した場合におけるストリーマ放電光のス ペクトルならびに発光像の過渡的変化を調べ, ガスの組成 やケーブル長が放電の広がりに及ぼす影響を検討するとと もに同軸円筒型プラズマ反応器を用いて排ガス処理実験を 行った。弚れらの結果を以下に要約する。

(1) ガラス板の挿入された針対平板電極を用いて，極 性反転繰り返しパルス放電光のスペクトルの時間的変化を ケーブル長ごとに調べたところ，ケーブルが短いほどギャッ プ間での放電の繰り返し数が多くなることを確認した。

(2) ケーブル長 $50 \mathrm{~m}$ において, 針先から進展する放電 光の過渡的変化を観測した。初回反転時には数多くの放電 チャネルが放射状に伸びており，比較的広い空間が放電に 曝されているのに対して, 繰り返しの後半段階では, 放電 チャネルの広がりは認められなかった。 
( 3 ) 同軸円筒型反応器を用いて, 弚れぞれのケーブル長 ごとに模擬排ガスに対する NO 除去率を測定した。繰り返 しの過程において消費された全放電エネルギーの中で, NO の酸化処理に寄与しているのは, 初回および 2 回目の反転 時に消費された放電エネルギーであり，弚れ以降の放電の 酸化処理に対する寄与は少ないことがわかった。

本研究の一部は, JFE21 世紀財団 2005 年度大学研究助 成金交付研究の助成を得て行われた。

(平成 17 年 6 月 20 日受付, 平成 18 年 8 月 11 日再受付)

\section{文献}

(1) O. Tokunaga: "Electron Beam Irradiation Technology for Purification of Flue Gas", Proc. Inst. Electrostatics Japan, Vol.19, No.4, pp.296-300 (1995-4) (in Japanese)

德永興公 : 「電子ビーム照射による排ガス処理技術」, 静電気学誌, 19, 4, pp.296-300 (1995-5)

（2）南條光章：環境触媒一実際と展望一共立出版 (1997-3)

( 3 ) K. Sano and Y. Yoshioka: "Effect of Oxygen Injection and HC Addition on NO Removability of Ozone Injection Method", IEEJ Trans. FM, Vol.123, No.10, pp.1030-1035 (2003-10) (in Japanese)

佐野和慶・吉岡芳夫 :「オゾン注入法による NO 除去性能の酸素注入 と HC 添加効果」, 電学論 A , 123, 10, pp.1030-1035 (2003-10)

(4) A. Mizuno: "Gas Cleaning Utilizing Non-Thermal Discharge Plasma", Proc. Inst. Electrostatics Japan, Vol.19, No.4, pp.289-295 (1995-4) (in Japanese)

水野 彰:「放電による排ガス処理技術」, 静電気学誌, 19,4 , pp.289-295 (1995-4)

( 5 ) A. Mizuno, J. S. Crements, and R. H. Davis: "A method for the removal of sulfur dioxide from exhaust gas utilizing pulsed streamer corona for electron energization", IEEE Trans. Industr. Applic., Vol.IA-22, No.3, pp.516-522 (1986-6)

(6) T. Yamamoto, K. Ramanathan, P. A. Lawless, D. S. Ensor, J. R. Newsome, N. Plaks, and G. H. Ramsey: "Control of Volatile Organic Compounds by an ac Ferroelectric Pellet Reactor and a Pulsed Corona Reactor", IEEE Trans. Industr. Applic., Vol.28, No.3, pp.528-534 (1992-6)

( 7 ) S. Masuda and H. Nakao: "Control of NOx by Positive and Negative Pulsed Corona Discharges", IEEE Trans. Industr. Applic., Vol.26, No.2, pp.374-383 (1990-3)

( 8 ) T. Hammer, S. Broer, and T. Kishimoto: "Pulsed Excitation of Silent Discharges for Diesel Exhaust Treatment", J. Adv. Oxid. Technol., Vol.4, No.4, pp.368-374 (1999-4)

(9) G. Dinelli, L. Civitano, and M. Rea: "Industrial Experiments on Pulse Corona Simultaneous Removal of NOx and $\mathrm{SO}_{2}$ from Flue Gas", IEEE Trans. Industr. Applic., Vol.26, No.3, pp.535-541 (1990-6)

(10) T. Namihira, S. Tsukamoto, D. Wang, S. Katsuki, R. Hackam, H. Akiyama, Y. Uchida, and M. Koike: "Improvement of NOx Removal Efficiency Using Short Width Pulsed Power", IEEE Trans. Plasma Sci., Vol.28, No.2, pp.434-442 (2000-4)

(11) T. Yamamoto, C. Yang, M. Beltron, and Z. Kravets: "Plasma Assisted Chemical Reacter for NOx Dcomposition", IEEEIAS Mtg., Oct. 5-9, 1997, pp.1956-1960 (2004-1)

(12) Y. Yoshioka: "Application and Mutual Comparison Methods of Exhaust Gas Treatment Technology", T. IEE Japan, Vol.122-A, No.7, pp.676-682 (2002-7) (in Japanese) 吉岡芳夫 : 「各種非熱平衡プラズマによる排ガス浄化技術の適用法 と相互比較法」, 電学論 A, 122, 7, pp.676-682 (2002-7)

(13) K. Kadowaki, K. Yamaga, S. Nishimoto, and I. Kitani: "Effect of Pre-Charging to Plasma Reacter on Repetitive Barrier Discharges Produced by Reciprocal Traveling Wave Voltage Pulse", IEEE Trans. Plasma Sci., Vol.32, No.5, pp.1835$1842(2004-1)$
(14) K. Kadowaki, S. Nishimoto, and I. Kitani: "Repetitive Discharges in a Corona Reactor Produced by a Reciprocal Traveling Voltage Pulse in a Coaxial Cable", Jpn. J. Appl. Phys., Vol.42, Part 2, No.6-B, pp.L688-L690 (2003-6)

(15) K. Yamaga, K. Kadowaki, S. Nishimoto, and I. Kitani: "NO Removal with Repetitive Discharges Caused by Reciprocal Traveling Wave Voltage Pulse in a Coaxial Cable", IEEJ Trans. FM, Vol.124, No.11, pp.987-992 (2004-11) (in Japanese)

山賀圭介・門脇一則·西本 榮·木谷 勇: 「ケーブル内進行波の往 復による繰り返し反転パルス放電を用いた NO 除去」, 電学論 $\mathrm{A}$ ， 124, 11, pp.987-992 (2004-11)

(16) M. J. Kushner: "Monte-Carlo Simulation of Electron Properties in RF Parallel Plate Capacitively Coupled Discharges", J. Appl. Phys., Vol.54, pp.4958-4965 (1983-9)

松田栄司 (学生員) 1981 年 9 月 26 日生。 2006 年 3 月

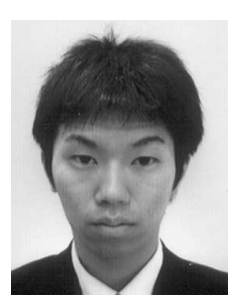
愛媛大学大学院理工学研究科博士前期課程修了。 同年 4 月日東電工 (株) 入社。在学時, パルスパ ワーを用いた排ガス処理, 排水処理に関する研究 に従事。

門 脇 - 則 (正員) 1965 年 11 月 22 日生。1990 年 3 月愛 媛大学大学院工学研究科電気工学専攻修士課程修 了。同年 4 月, 日東電工 (株) 入社。1996 年 10 月愛媛大学工学部電気電子工学科助手, 2003 年 11 月同助教授, 現在に至る。博士 (工学)。主とし て絶縁材料の破壞現象と空間電荷分布に関する研 究, パルスパワー応用に関する研究に従事。IEEE 会員。

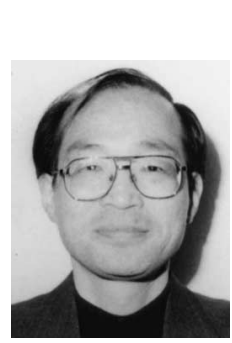

榮 (非会員) 1946 年 12 月 15 日生。 1971 年 4 月愛 媛大学工学部文部技官，現在技術専門職員。直流 破壊前駆像の観測系の開発，圧力波信号のウェー ブレット解析，極性反転繰り返しパルス発生装置 の開発に従事。

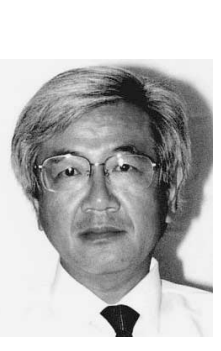

勇 (正員) 1944 年 7 月 14 日生。6 8 年 3 月大阪大 学工学部電気工学科卒業。同年 4 月三洋電機 (株) 入社。71 年愛媛大学工学部電気工学科助手, 現在 同学部電気電子工学科教授。工学博士。主として, 液体，固体および複合体の高電界電導と，破壊現 象の研究に従事。応用物理学会, IEEE 会員。 